\title{
Early Secondary Succession Following Res- toration and Reseeding Treatments in Northern Arizona
}

\section{M.B. HESSING AND C.D. JOHNSON}

\section{Abstract}

Reseeding, with and without disc harrowing, building of water bars, and piling of slash on utility corridors (restoration), was studied on access roads and pylon sites following construction of the 500 kV Navajo Project Southern Transmission Line in 1973. Reseeding was not successful. Restoration either had no significant positive effect on revegetation or slowed plant succession in the following 4-year period, or had a deleterious effect on amount and quality of revegetation due to the destruction of climax vegetation which survived powerline construction.

Reseeding rangeland has been shown to be both successful and economically feasible by many (e.g. Godfrey 1979, Kearl and Cordingly 1975). Successful seeding, however, has been shown to be dependent upon prevailing weather conditions; weed control (Herbel et al. 1973); seedbed preparation (Struth and Dahl 1974, Hull 1974); and sometimes, pretreatment of seeds to enhance germination (Voigt 1978).

In previous papers (Hessing et al. 1981a,b) we described the secondary succession of plants after construction of the $500 \mathrm{kV}$ Navajo Project Southern Transmission Line which connects the Navajo Generating Station at Page, Ariz., with Phoenix. In this paper we describe the effects of reseeding and restoration treatments on the initial course of secondary succession. We used an experimental design which allowed us to describe succession following restoration either separately or together with reseeding.

The sequence of powerline construction was that a survey strip was bulldozed in 1972. The powerline was constructed in the spring and early summer of 1973 with part of the survey strip serving as an access road for construction. All restoration and reseeding was done after construction in the summer of 1973. Reseeding occurred at the beginning of the annual summer rainy season, thus providing the seeds with a moist seed-bed.

\section{Methods}

Three studies were made. Study 1 was located in a juniper woodland near Williams, Ariz., several kilometers south of the site described in Hessing et al. (1981a). One-seed juniper (Juniperus monosperma (Engelm.) Sarg.) and pinyon pine (Pinus edulis Engelm.) are the major components of the plant community with the junipers dominant. Large shrubs are also common low profile vegetation. Soils have a rocky surface with shallow to moderately deep clay subsoils occurring over volcanic cinders and basaltic flows. Studies 2 and 3 were located on grassland near Drake, Ariz. several kilometers east of the area described by Kruse et al. (1979) and Hessing et al. (1981b). As a result of a United States Forest Service "Range Improvement Project" in 1951, this area was transformed from a pinyon-juniper woodland into a grassland. Perennial grass cover is extensive with lesser numbers of annual grasses and herbs. Soils are generally shallow, rocky and gravelly loam surfaces over limestone or calcareous limestone.

Three 61.0-m sections of access road were sampled at study 1 .

Authors are with the Department of Biological Sciences. Northern Arizona University, Flagstaff 86011 .

Authors are grateful to Arizona Public Service Company, Salt River Project, and Tucson Gas and Electric Company for providing funds for this research.

Manuscript received September 8, 1980.
Sampling consisted of line transects $4.6 \mathrm{~m}$ in length which were placed perpendicular to the 3 sections at $3.0-\mathrm{m}$ intervals. Transects were centered on the access roads in studies 1 and 2 . Sampling was done in summer 1975, spring and summer 1976, and spring 1977 at all 3 study areas. One section of road received a treatment of restoration and reseeding. Seeding was performed using a rangeland drill seeder. Restoration consisted of disc harrowing, followed by the formation of waterbars and piling juniper slash at strategic places to deter erosion and protect germinating seeds. A second section of road received similar restoration but no reseeding. The third section of road received no treatment and served as a control.

In study 2, plant growth along two $91.4 \mathrm{~m}$ sections of restored access road was sampled. One plot was reseeded and the other was not. As in study 1 , line transects $4.6 \mathrm{~m}$ in length were placed perpendicular to the road at $3.0 \mathrm{~m}$ intervals in study 2 .

In study 3 the disturbed, unrestored areas under four towers (pylons) were monitored. Two tower areas were reseeded, the other two were not. Tower sites were sampled by measuring eight $6.1-\mathrm{m}$ transects which radiated from the center of the square formed by the base of the tower. Generally, only herbaceous species and small woody plants were present.

A series of one-way analyses of variance (ANOVA's) were performed on the data from each census period. In most cases, the one-way ANOVA is identical to a student $t$-test. A series of twoway ANOVA's were performed on different combinations of yearly data.

A total of $15.3 \mathrm{~kg} /$ ha of seed of eight species of plants was used on all reseeded plots. The most abundant of these were western wheat-grass, side-oats grama, and Russian wildrye (Table 1).

\section{Results and Discussion}

\section{Study 1}

In each sampling period there were statistically signifi$\operatorname{cant}(p=.002)$ differences in cover among the three sections of road (Fig. 1).

The dominant species on the control plot were all perennial grasses. The absolute cover (total length of transect covered by all species) of perennial grasses (Fig. 2) was always higher on the control plot. Generally, the control plot shows the most favorable response. This plot had greater herb cover in half the censuses, and it consistently had a greater absolute cover of perennials. It generally had a lower diversity - a trait which has been linked with more mature seral stages in this area (Hessing et al. 198la, b).

This favorable response can be simply explained using the initial floristic principle (Egler 1954). Although use of the road completely destroyed vegetation in the two ruts, much of the original

Table 1. Species used in reseeding.

\begin{tabular}{lll}
\hline \hline & & $\begin{array}{l}\text { Seeding } \\
\text { rate } \\
(\mathrm{kg} / \mathrm{ha})\end{array}$ \\
Species & Common name & 4.4 \\
\hline Agropyron smithii & western wheatgrass & 2.7 \\
Elymus junceus & Russian wildrye & 0.5 \\
Eragrostis curvula & weeping lovegrass & 5.0 \\
Bouteloua curtipendula & sideoats grama & 0.25 \\
Bouteloua gracilis & blue grama & 0.5 \\
Atriplex canescens & fourwing saltbush & 0.25 \\
Cowania mexicana & cliff-rose & 1.7 \\
Melilotus officinalis & yellow sweetclover & $15.3 \mathrm{~kg} / \mathrm{ha}$ \\
& Total &
\end{tabular}


vegetation remained at the road edge and even on the hump between the two ruts. Disc harrowing and drill seeding seemed to destroy almost all of the original climax vegetation. Also, no section of road was disc harrowed to a width less than about $5 \mathrm{~m}$.

\section{Study 2}

There was no difference in a mount of cover between sections of seeded and unseeded road. This was tested by combining cover from all censuses in two-way analysis of variance $(p=2212)$. The two plots varied in their responses to spring and summer seasons (Fig. 1).

The dominant plants on each section of road differed. In spring, 1976, heron-bill (Erodium cicutarium) was dominant on both road sections. The dominant plants differed among years and seasons on the same plot and in the spring censuses were often found in the surrounding climax vegetation. Plantago purshii, Layia glandulosa, heron-bill, and Eriastrum diffusum fall into this category. Many of the dominant plants in the summer censuses seem to be pioneer successional species, as they are absent from the surrounding climax vegetation, but are common around cattle tanks (bulldozed depressions designed to capture rainfall for use by livestock). Pioneer successional species are Salsola kali, Descurainia sophia, Eriogonum densum, Chenopodium incisum, and possibly Sitanion hystrix.

Because the dominant plants observed seemed to be species specially adapted to large scale disturbances, and because the adjacent sections of road contained no edge of undisturbed plants, we expected higher, more constant similarity. However, few of the species on either plot were desirable forage plants and none were species which had been sceded.

Differences between treatments were minor; neither showed consistent, advantageous effects.

\section{Study 3}

The disturbance at each tower site differed slightly due to the amount of clearance and leveling necessary. Also, since the towers were separated by long intervals (the total interval of four towers was approximately $1 \mathrm{~km}$ ), there existed a large variability in towerto-tower conditions. Large damp spots were observed in the spring under the towers when none could be found in the surrounding area, suggesting that towers collected dew, which then dripped to the ground. Towers created shade and probably concentrated rain also, but this was not measured or observed.

In spring 1976, there was more cover on the reseeded towers (Fig. 1). This was the only census in which significance was observed $(P=.0007)$ using a two-way analysis of variance. The $53 \%$

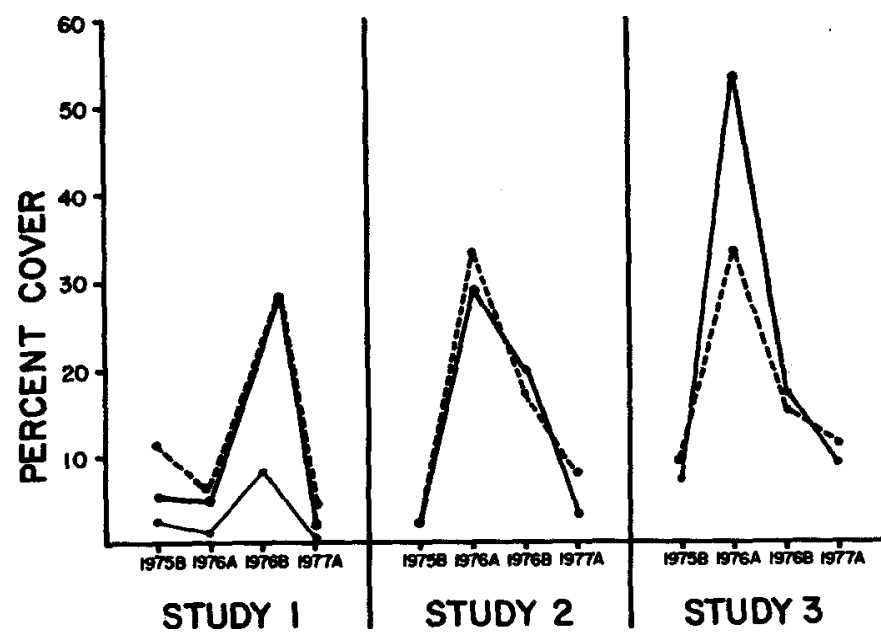

Fig. 1. Percent of the ground covered by plants ( \pm standard error) in Studies 1,2,3. In Study 1 . thin, solid line = restored only; broad solid line $=$ restored and reseeded; and dashed line $=$ no treatment. In Study 2, broad solid line = reseeded road; dashed line = unseeded road. At Study 3, broad solld line $=$ reseeded towers; dashed line $=$ unseeded lowers. A = spring sample, $B=$ summer sample. cover value recorded on the two seeded tower areas in the spring of 1976 was the highest herb cover value recorded in this 7-year study. No doubt this high value was due to the moisture accumulating below the tower. In summer there is little dew and the effect is less pronounced.

The seeded plot had most cover from perennial grasses (Fig. 3). However, vegetation under both sets of towers consisted mostly of perennial species (Table 2).

Table 2 lists the dominant species from the tower plots. The plants of both treatment areas are primarily perennials. It is unlikely that reseeding affected the establishment of these components of the climax vegetation because they were not included in the reseeding mixture (Table 1). It is probable that the original climax herbaceous vegetation or their seeds were never disturbed at these tower sites.

\section{Reseeded Species}

Of those species used in reseeding, only Bouteloua gracilis and $B$. curtipendula were later found on any reseeded area. These are common species in the climax vegetation, but do not germinate well (Briske and Wilson 1978), and the observed individuals were probably remnants of the original vegetation. In the few instances where reseeded plots responded more favorably than unseeded plots, the response was never due to a reseeded species.

This does not prove that reseeding had no effect. Seed predators could concentrate their efforts on this abundant supply, thus giving seeds from the surrounding community and those originally present in the soil an advantage. Reseeded species may germinate the first year only and retard erosion in this critical period. The intense reseeding (approximately $15.3 \mathrm{~kg} / \mathrm{ha}$ ) may create allelochemic effects which repress the germination of many species. Linhart

Table 2. Percent cover of the dominant species at Studies 2 and 3 . An asterisk indicates an annual species.

\begin{tabular}{llll}
\hline \hline 1975 & Spring 1976 & 1976 & Spring 1977 \\
\hline $\begin{array}{llll}\text { Study 2 } \\
\text { Unseeded }\end{array}$ & & & \\
\hline HA GR 43.6* & ER CI 39.1* & SA KA 40.2* & SA KA 35.9* \\
EU CA 22.6* & ER DI 16.8* & HA GR 27.2* & PL PU 17.7* \\
AS AR 19.6 & PL PU 7.2* & ER DE 14.3* & ER CI 12.0* \\
ER WR 8.1 & SA KA $7.0^{*}$ & SI HY 4.4 & SI HY 5.8
\end{tabular}

Seeded

\begin{tabular}{llll}
\hline HA GR 24.5* & ER CI 45.5* & ER DE 63.4* & ER DE 29.7* \\
HI MU 21.5 & ER DE 24.9* & CH IN 20.1* & SA KA 16.3* \\
SA KA 18.6* & LA GL 8.5* & AS TA 3.2 & ER Cl 10.5* \\
ER WR 15.8 & DE SO 4.6* & HA GR 2.9* & LA GL 9.2*
\end{tabular}

Study 3

Unseeded
GU LU 35.6

ER WR 25.9

UNK 1210.0

AS AR 7.0

AM HY $6.9 *$

HA GR 2.0

\section{PL PU 19.8* \\ ER CI 17.0* \\ HO PU 14.6* \\ ER DI 9.7* \\ AS AR 7.3 \\ UNK $7 \quad 5.0$}

Reseeded

ER WR 46.2

AS AR 16.2

UNK $12 \quad 8.9$

EU AL 8.6

GU LU 4.5

AM HY $4.3^{*}$

$\begin{array}{ll}\text { HO PU 37. } & \text { SI HY 21.3 } \\ \text { PL PU 12.8* } & \text { HA GR 19.1 } \\ \text { SI HY 11.3 } & \text { ER WR 18.4 } \\ \text { HY VE 11.0 } & \text { CH IN 11.4* } \\ \text { ER DE 10.1* } & \text { AS AR } 7.0 \\ \text { PA OB 8.9 } & \text { GR 32 } 6.7\end{array}$

GU LU 21.6

HA GR 15.0

ER WR 13.2

DE CO 12.4

AS AR 8.6

HI MU 6.3

GU LU 27.4

ER WR 12.0

SI HY 11.4

AS AR 7.5

HO DR 7.3

HI MU 6.5
1Key: AMaranthus Hybridus, ASter ARenosus, ASter TAnacetifolius. CHenopodium INcisum, DEscurainia SOphia, DEsmanthus COoleyi, ERiastrum DIffusum, ERiogonum DEnsum, ERiogonum WRightii, ERodium CIcutarium, EUphorbia ALbomarginata, EUphorbia CApitellata, EUphorbia SPecies unknown, GRass 32, GUtierrezia LUcida, HAplopappus GRacilis, HIlaria MUtica, HOffmanseggia DRepanocarpa, HOrdeum PUsillum, HYbanthus VErticillatus, LAyia GLandulosa, PAnicum OBtusum, PLantago PUrshii, SAlsola KAli, Shanton HYstrix, UNknown 7 (Polemoniaceae), UNknown 12 


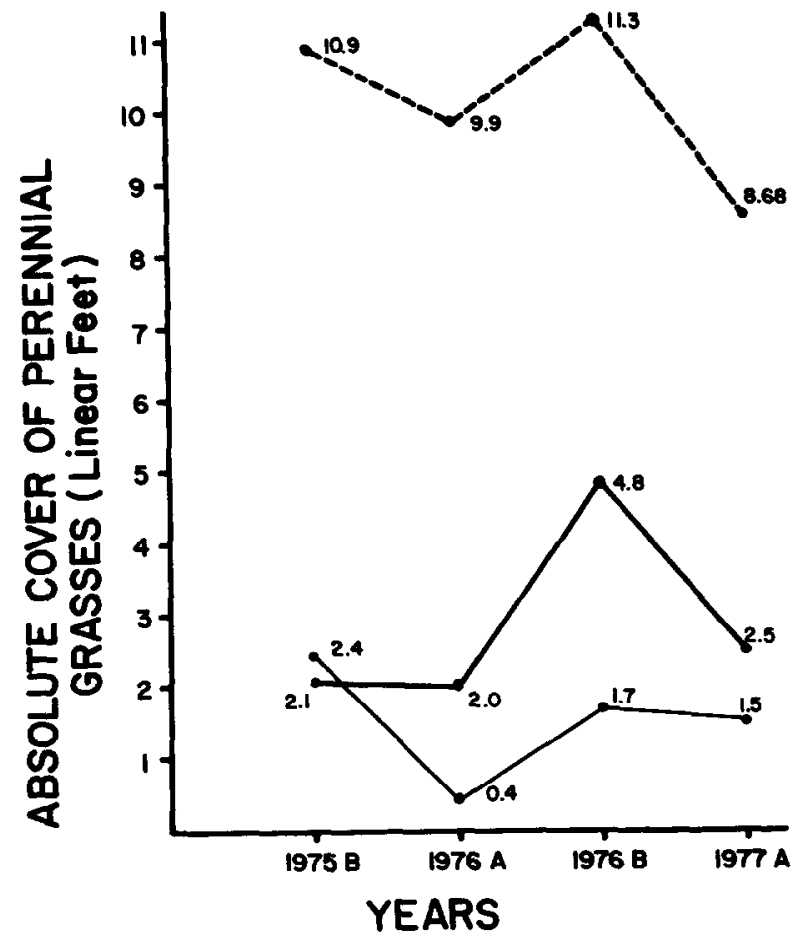

Fig. 2. Absolute cover in linear feet of perennial grasses at Study 1. Thin, solid line = restored only; broad, solid line = restored and reseeded; dashed line $=$ no treatment. $A=$ spring sample, $B=$ summer sample.

(1976) has shown that germination in some annuals is not affected by seed clumping whereas seed germination in some persistent species is.

We conclude, however, that reseeding did not create the desired effect, nor did reseeded areas consistently differ from untreated plots in any of the attributes we measured.

These areas and the untreated road did support climax vegetation. Lack of climax vegetation on all the disc harrowed sections of road studied is explained by the fact that disc harrowing or some aspect of the restoration treatment destroys the climax herb vegetation but the initial clearance does not. The disc harrow could not fit under the pylons.

Struth and Dahl (1974) report results which parallel ours. Seeding results were poor or, as in our study, total failures when the original grass was destroyed. A positive response required careful seeding technique and a subtle array of climatic factors. Successful seed germination usually requires optimum temperature, and moisture regimes and often chemical or scarification pretreatment. Voigt (1978) reports that only 3 of 20 prairie forb species germinated with no pretreatment. Young and Evans (1977) and Herbel et al. (1973) report failure in germination and initial survivability of usually successfully seeded species during droughty conditions. Robocker and Schirman (1976) reported that successful seeding was dependent on weed control and soil fumigation with microbial agent.

Heady (1975) reported fewer successful seedings in areas with less than $1.66 \mathrm{~cm}$ of rain per month. Although rainfall at studies 2 and 3 averaged $2.76 \mathrm{~cm}$ per month (Sellers and Hill 1974), there was little or no rainfall during September, October, and December following reseeding. Rainfall at study 1 averaged $3.24 \mathrm{~cm}$ per month.

It seems possible that Egler's initial floristic component was the most important aspect of secondary plant succession in these restoration experiments because the success of restoration treatments was dependent upon the amount of original vegetation

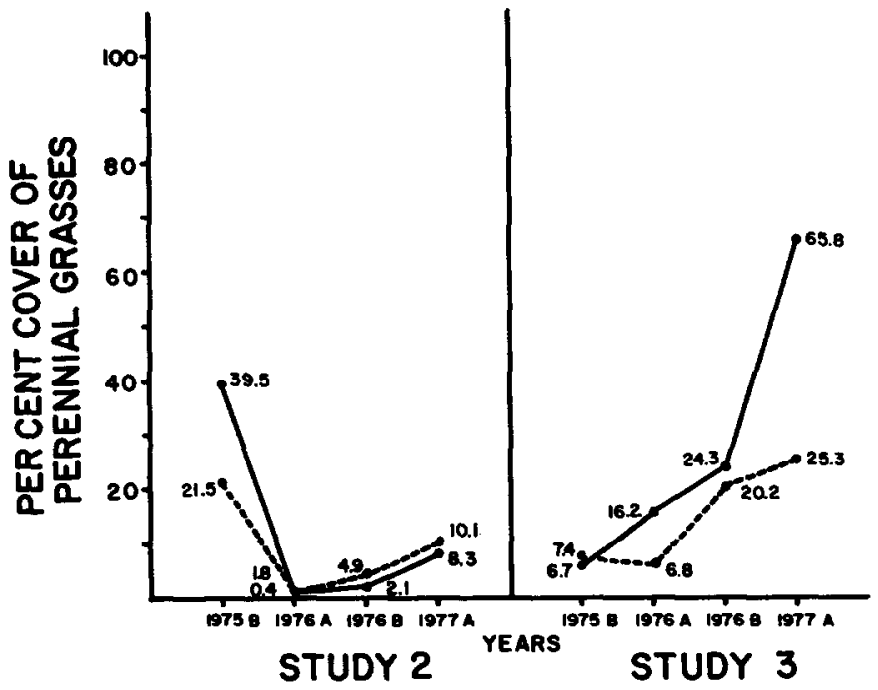

Fig. 3. Percent of the herbaceous community composed of perennial grasses at Studies 2, 3. Solid line $=$ reseeded road or tower; dashed line $=$ unseeded road or rower. $A=$ spring sample, $B=$ summer sample. Data points 1.8 and $7.4=$ unseeded.

capable of regrowth. Restoration treatments based on this principle might have superior outcome when germination and survivability variables are unpredictable.

\section{Literature Cited}

Briake, D.D., and A.M. Wilson. 1978. Moisture and temperature requirements for adventitious root development in blue grama seedlings. J. Range Manage. 31:174-178.

Egler, F.E. 1954. Vegetation science concepts I. initial floristic composition, a factor in old-field vegetation development. Vegetatio 4:412-417.

Godfrey, B.E. 1979. Utilization practices and the returns from seeding an area to crested wheatgrass. J. Range Manage. 32:171-174.

Heady, H.F. 1975. Rangeland Management. McGraw-Hill, Inc. 460 p.

Herbel, C.H., G.H. Abernathy, C.C. Yarbrough, and D.K. Gardner. 1973. Root plowing and seeding and rangelands in the southwest. J. Range Manage. 28: 193-197.

Hessing, M.B., C.D. Johnson, and R.P. Balda. 1981a. Early secondary succession of a juniper woodland in a Northern Arizona powerline corridor. Southwestern Naturalist. (accepted)

Hessing, M.B., C.D. Johnson, and R.P. Balda. 1981b. Secondary succession of desert grassland in north-central Arizona powerline corridors. J. Environ. Manage. 13:55-69.

Hull, A.C. 1974. Species for seeding arid rangela nd in Southern Idaho. J. Range Manage. 27:216-218.

Kearl, W.G., and R.V. Cordingly, 1975. Cost and returns from reseeding plains ranges in Wyoming. J. Range Manage. 28:437-441,

Kruse, W.H., R.P. Balda, M.J. Simono, A.M. Macrander, and C.D. Johnson. 1979. Community development in two adjacent pinyon-juniper eradication areas twenty-five years after treatment. J. Environ. Manage. 8:237-247.

Linhart, Y.B. 1976. Density dependent seed germination strategies in colonizing versus non-colonizing plant species. J. Ecol. 64:375-380.

Robocker, W.C., and R.D. Schirman. 1976. Reseeding trials on Columbia basin rangelands dominated by annual grasses. J. Range Manage. 29:492-497.

Sellers, W.D., and R.H. Hill. 1974. Arizona climate, 1931-1972. Univ. Arizona Press, Tucson. $60 \mathrm{p}$.

Struth, J.W., and B.E. Dahl. 1974. Evaluation of rangeland seedings following mechanical brush control in Texas. J. Range Manage. 27:146149.

Voigt, J.W. 1978. Seed germination of true prairie forbs. J. Range Manage. 30:439-441.

Young, J.A., and R.A. Evans. 1977. Squirreltail seed germination. J. Range Manage. 30:33-36. 